\title{
Required and Possessed University Graduate Employability Skills: Perceptions of the Nigerian Employers
}

\author{
Adebakin, Azeez B ${ }^{1, *}$, Ajadi, O. Timothy ${ }^{1} \&$ Subair, S. Tayo ${ }^{1}$ \\ ${ }^{1}$ Department of Educational Management, Faculty of Education, Obafemi Awolowo University, Ile - Ife, Nigeria \\ *Corresponding author: Department of Educational Management, Faculty of Education, Obafemi Awolowo \\ University, Ile - Ife, Nigeria. Tel: 234-805-536-5175. E-mail: adebakinazeez@yahoo.com
}

Received: January 13, 2015

Accepted: February 12, $2015 \quad$ Online Published: April 14, 2015

doi:10.5430/wje.v5n2p115

URL: http://dx.doi.org/10.5430/wje.v5n2p115

\begin{abstract}
University is a place where skilled labour is produced for societal and global consumption. This is premised on the fact that education provided at this level enhances human capital development which widens employment opportunities. However, there seems to be disparity over the skills required and those possessed by graduates from Nigerian universities. As a result, many university graduates are either underemployed or unemployed. The study adopted descriptive survey research design. Using stratified and simple random sampling techniques, a total of 300 employers of labour drawn from the manufacturing, banking and finance, education, and telecommunication industries in Lagos State constituted the sample frame. A Skill Assessment Questionnaire (SKAQ) was designed to elicit information from the participants. The results obtained showed that skills required of university graduates as perceived by employers were analytic and problem solving (98\%), decision - making $(98.3 \%)$, risk management (96.7\%), leadership (98\%), information and communication (97.7\%), team-work (99\%), official communication (97.7), and English proficiency and literacy skills (97\%) while skills possessed by university graduates were English proficiency and literacy (58\%) and information and communication skills (53\%). These results showed disparity in both the employers required skills and those possessed by the university graduates. The study, therefore, recommends that Nigerian university curriculum should be revised to reflect courses that will teach the required skill by employers.
\end{abstract}

Keywords: employers; employability skills; university graduates

\section{Introduction and Literature Review}

Globally, university is fundamental to the construction of a knowledge economy and society. It is a place where skilled labour is produced for societal and global consumption. Adepoju and Fadokun, (2009) inform that education provided at this level widens the socio-economic growth of human and capital development of any nation. In addition, the Federal Government of Nigeria (2004) stressed that education at this level shall make optimum contribution to national development by intensifying and diversifying its programmes for the development of high level manpower within the content of the needs of the nation; making professional course contents to reflect the national requirements; making all students, as part of a general programme of all round improvement in University education to offer general study courses such as history of ideas, philosophy of knowledge and nationalism.

University education is the main instrument to prepare individuals for a rapidly-changing, increasingly-demanding world of work and to improve their employability. Chang (2004) reported that an individual's employability depends on several factors among which are self-belief, an ability to secure and retain employment, ability to improve productivity and income-earning prospect of individuals. Thus, these factors can aid new employment opportunities in an advanced knowledge, communications and technological society.

Employability as a concept seems to attract diverse meaning from various authors. Hillage and Pollard (1998) view employability as having the capability to gain initial employment, maintain the employment and obtain new one if need be. According to Harvey and Bowes (1998) employability is the ability of graduates to gain employment which has relationship with their university training and standard of the graduates. Kamal (2006) views it from the 
employees point of view on the propensity of the graduate to exhibit attributes which the employers anticipate will be necessary for the future effective functioning of their organisations. However to Harvey, Lock and Morey (2002), employability is associated with graduate employment and measured as an educational outcome under the auspices of first destination statistics which shows the percentage of graduate in employment six months after graduation.

Pierce (2002), Knight and York (2001) focused on graduates' employability skills as abilities to synthesis their personal and academic skills. Raybould and Sheard (2005) on their own concluded that nearly two-thirds of all graduate vacancies are open to university graduates from any discipline. It was further stated that the type of skills required for the job is dependent on the role to be carried out by the graduates within a particular organisation.

In the 1970s, 1980s and early 1990s, Nigerian university graduates were employed at the point of graduation (those who are above National Youth Service Age) or immediately after the one year NYSC exercise. This is because at this time, demand for university graduates with required job skills was higher than the supply. In addition, Oni (2001) informs that university graduates at the time can compete with graduates from anywhere in the world. This allowed them to also have access to international employment opportunities.

Contemporarily, employability skills became an issue for the providers of university education and the graduates themselves. The prime intent of most students attending university is not to study or have in-depth knowledge of a course but to enhance their employability status (Stewart and Knowles, 2000). Studies by De la Harpe, Radloff and Wyber (2000), Adams (2006), and Adebakin (2014) reported that university graduates are poorly prepared for world of work because there is a mismatch between the education and training (undergraduate programmes) provided by universities and vacancies available in the labour market. Pitan and Adedeji (2012) also concluded that there is a disparity between the skills acquired by university graduates and the ones needed by employers of labour.

De la Harpe, Radloff and Wyber (2000) concluded that there is concern worldwide that the existing undergraduates' programmes in the universities are not producing graduates with the kind of lifelong learning and generic skills which they need to be successful in their chosen careers. As a result, Yorke (2001) suggested two main concepts of employability: the first is the ability of graduates to tackle graduate jobs while the second is the ability of the graduates to get a job. Therefore, there is need for graduates to develop and improve their employability skills from time to time to be able to match up with the requirements of the employers of labour.

Chang (2004) in his own explanation said that university graduates are unemployed because they do not possess the right degrees. Graduates of some specific disciplines in humanities are already abundant in the labour market whereas graduates in engineering and sciences are still in high demand. Another reason is that degree certificate from universities no longer qualify graduates for getting their first job. Instead, most graduates are underemployed by getting hired for jobs below their academic qualifications with lesser pay when compared to what should be earned. Chang (2004) concluded that graduates need to possess analytical and technological skills in order to be able to contribute meaningfully to organisations' success and growth.

Most often, employers of labour prefer to employ university graduate who have self-confidence, optimist and those that can bring innovation to the work place. Little (2001) asserts that employers want graduates who can use their abilities and skills to evolve the organisation and who can participate in innovative teamwork. Employers also value critical thinking as this is required for innovation and anticipatory leading change (Harvey, 2001).

One of the challenges with skills agenda and initiatives in higher education is the assumption that skills have the same meaning in education and employment contexts (Holmes, 2001). But Dunne, Bennet and Carve (2000) observed that both the universities and employers of labour did not have common meaning for skill. This makes it imperative for the university and employer of labour to have the same focus as regards employability skills.

In the United Kingdom (UK), university graduates employability is often associated with graduate employment and measured as an educational outcome under the auspices of firs destination statistics. Harvey et. al. (2002) stated that these statistics show the percentage of graduates in employment six months after graduation. Earlier, Smith, McKnight and Naylor (2002) developed and utilized performance measures for some universities in UK. It was revealed that at an individual level, the probability of a university graduate unemployment or inactivity six months after graduation is influenced strongly by the individual's class of degree, course of study, previous educational background and socio-economic background of the students. This shows that in addition to the class and quality of degrees and level of transferable skills possessed by students, other factors come into play when determining employability.

Contrarily, graduates' possessed employability skills are more important than the course of study and class of degree graduated with (Harvey, 2001). This implies that the course of study is not as important as the graduates' ability to 
handle and manage complex information effectively. In Malaysia, the government conducted a survey on Malaysian university graduate employability skills and found that about 60,000 Malaysians graduates were unemployed because of lack of experience, poor English communication skills and study of courses that are not relevant to the market need (Malaysian Today, 2005). It was further revealed that most unemployed university graduates studied business related courses. The report showed that $70 \%$ graduates from the public universities in Malaysia are still unemployed. This is in contrast with Suresh (2006) who reported that $20 \%$ graduates from private universities and $34 \%$ graduates from foreign universities are unemployed.

Similarly, in South Africa, Pauw, Ooshuizen and Westhuizen (2008) found that many university graduates were not employed because they lack soft skills and workplace readiness. They reported that at the commencement of graduate careers, many students lack time management skills. These are some of the reasons advanced for many university graduates failure in recruitment tests. Also, in Ghana, Boateng and Ofori-Sarpong (2002), found that employers often regard recent university graduates as those who lack the basic skills to complete simple routine assignments, which gives the impression that certification is a mere formality rather than an indication of achievement.

In addition, Lawrence (2002) adds that the United States of America is also experiencing the problems of university graduates employment deficit due to lack of transferable skills by the graduates. Daring (1997) explains that studies by employers of university graduates have repeatedly stressed the priority given to the university graduates personal transferable skills. All over, employers of labour according to Lawrence (2002), emphasize that employability skills are foundational skills that apply across board, no matter what job employees perform. Employers of university graduates prefer to employ balanced graduates who can combine academic intelligence with employability skills such as communication, problem solving and interpersonal.

In Nigeria, both the public and private organisations have decried the quality of university graduates turnout from Nigerian universities and the need to expend a lot of human and material resources on newly recruited university graduate to achieve desired results from the graduates recruited.

\section{Statement of the Problem}

Nigeria is a nation of about 150 million people with 128 universities (40 Federal, 38 States and 50 Private). The universities witnessed unprecedented increase in enrolment and turnout rates in recent time. In the same vein, the society is experiencing increase in the number of university graduates unemployment. This situation is not healthy for the economic growth and development of the country and standard of living of the citizens. Therefore, this study investigates the employers required and university graduates perceived employability skills.

\section{Research Questions}

1) What are the employers' perceived skills required of university graduates?

2) What are the employers' perceived ratings of skills possessed by Nigerian university graduates?

\section{Research Hypothesis}

There is no significant difference between the employers' perceived skills possessed by public and private university graduates.

\section{Methodology}

The population of study comprised all university graduate employers from different sectors of the economy as found available in Lagos State. The choice of Lagos in this study was based on it being the economic centre of the country and where many graduates rush to for jobs. Using stratified and simple random sampling techniques, the employers were reduced to those in the manufacturing, banking and finance, education and telecommunication industries. These four were considered representative of employers in this study because they appeared to be the fast growing areas in the recent times seeking fresh graduates from universities. From each industry, 75 participants were randomly selected thereby constituting 300 participants as the sample frame for the study. A self - designed instrument tagged "Skills Assessment Questionnaire (SKAQ)" was administered on the participants. The instrument has three sections. Specifically, section A contained items which measured the sectors that employ and institutions of university graduates in Nigeria (public or private). Section B and C measured employers' perceived skills and university 
graduates possessed skills respectively; and properties are as presented in Tables 1 and 2. The results obtained were analyzed using descriptive and inferential statistics specifically, simple percentages and t-test to answer the research questions raised and test the hypothesis formulated for the study.

\section{Results}

Research Question One: What are the employers' perceived skills required of university graduates?

To answer this, the participants' responses were calculated using simple percentages. The results are presented in Table 1.

Table 1. Employers' Perceived Skills Required of University Graduates

\begin{tabular}{llrrrrl}
\hline & \multicolumn{1}{c}{ Skills } & \multicolumn{4}{c}{ Employer } & \multirow{2}{*}{ Total } \\
\cline { 3 - 5 } S/N & & A & B & C & D & \\
\hline 1 & Analytic \& Problem Solving Skill & 73 & 75 & 73 & 73 & $295(98 \%)$ \\
2 & Team - Working Skills & 74 & 74 & 74 & 75 & $297(99 \%)$ \\
3 & English Proficiency \& Literacy Skills & 71 & 74 & 73 & 73 & $291(97 \%)$ \\
4 & ICT Skills & 74 & 75 & 73 & 75 & $297(99 \%)$ \\
5 & Leadership skills & 73 & 74 & 74 & 73 & $294(98 \%)$ \\
6 & Official Communication Skills & 72 & 74 & 74 & 73 & $293(97.7 \%)$ \\
7 & Decision - Making Skills & 74 & 74 & 74 & 73 & $295(98.3 \%)$ \\
8. & Risk Management Skills & 71 & 75 & 72 & 72 & $290(96.7 \%)$ \\
\hline
\end{tabular}

Key: $A=$ Manufacturing Industry; $B=$ Banking \& Finance Industry; $C=$ Education Industry and $D=$ Telecommunication Industry

Table 1 presents the employers' perceived skills required of university graduates. It shows that ICT skills (99\%) and team-work skills $(99 \%)$ were the highest skills required by employers. The employers as well required decision-making skills (98.3\%), leadership skills (98\%) and analytic and problem solving skills (98\%). However, official communication skills, English proficiency and literacy skills and risk management skills with varying values of $97.7 \%, 97 \%$ and $96.7 \%$ respectively were equally required by employers. The table therefore reveals eight major skills required by employers in the manufacturing, banking and finance, education and telecommunications industries. This implies that for university graduates to be gainfully employed in the Nigerian labour market, there is the need to possess the highlighted skills.

Research Question Two: What are the employers' perceived ratings of skills possessed by Nigerian university graduates?

To answer this, the participants' responses were calculated using simple percentages. Intervals used in the table were as conceptualized by the authors. The results are presented in Table 2 .

Table 2. Skills Possessed by Universities Graduates

\begin{tabular}{|c|c|c|c|c|c|}
\hline \multirow[t]{2}{*}{$\mathbf{S} / \mathbf{N}$} & \multirow[t]{2}{*}{ Skills } & \multicolumn{4}{|c|}{ Employers' Perceived Ratings } \\
\hline & & Excellent & Good & Fair & Poor \\
\hline 1. & Analytical \& Problem - Solving Skills & - & - & $43 \%$ & - \\
\hline 2. & Team - Working Skills & - & - & - & $39 \%$ \\
\hline 3. & English Proficiency \& Literacy Skills & - & $58 \%$ & - & - \\
\hline 4. & ICT Skills & - & $53 \%$ & - & - \\
\hline 5. & Leadership skills & - & - & - & $37 \%$ \\
\hline 6. & Official Communication Skills & - & - & $40 \%$ & - \\
\hline 7. & Decision - Making Skills & - & - & - & $35 \%$ \\
\hline 8. & Risk Management Skills & - & - & - & $38 \%$ \\
\hline
\end{tabular}

Key: Excellent-60\% - 100\%; Good-50\% - 59\%; Fair-40\%-49\%; Poor - 0\%-39\%

Table 2 presents employers' perceived ratings of skills possessed by Nigerian university graduates. The table shows that no employer rated the any university graduates' possessed skills excellent. Skills like English proficiency and 
literacy $(58 \%)$ and ICT $(53 \%)$ were rated good as possessed by university graduates. Meanwhile, analytical and problem solving skills (43\%) and official communication skills $(40 \%)$ were rated fair. Whereas, team work skills, risk management skills, leadership skill and decision-making skills were rated poor with obtained values of $39 \%, 38 \%$ $37 \%$ and $35 \%$ respectively. This shows that most of the skills possessed by university graduates were perceived as below expectations of employers.

Hypothesis: There is no significant difference between the employers' perceived skills possessed by public and private university graduates.

To test this hypothesis, participants' responses were subjected to mean and standard deviation after which the T-test statistic was employed. The results are presented in Table 3.

Table 3. Differences in the Employers' Perceived Skills Possessed by Public and Private University Graduates

\begin{tabular}{llllll}
\hline University & Mean & SD & N & t-cal. & t-tab. \\
\cline { 1 - 3 } & 78.31 & 13.27 & 150 & 1.15 & 1.96 \\
\cline { 1 - 2 } Private & 76.23 & 13.25 & 150 & & \\
\hline
\end{tabular}

$*$ Not Sig, $\mathrm{N}=300, \mathrm{df}=298, \mathrm{P}<0.05$

Table 3 shows that there is no significant difference in the employers' perceived skills possessed by public and private university graduates. The table reveals that the calculated t-value (1.15) is less than the critical t-value (1.96). This shows that the hypothesis is accepted. Therefore, there is no significant difference in the public and private university graduates' possessed skills as perceived by employers.

\section{Discussions}

Resulting from the findings on employers' required skills of university graduates is that employability is based on critical skills raging from ICT skills, team-work skills, decision-making skills, leadership skills, analytic and problem solving skills, official communication skills, English proficiency and literacy skills to risk management skills. This finding shows no difference in the skills university graduates need to work either in the manufacturing sector, banking and finance, education or telecommunication sectors. This finding supports Kamal (2006), who views that employability of graduates from the employers' point of view on the propensity of graduates to exhibit attributes which will be necessary for future effective functioning of their organisations. Lending credence to this is Little (2001) and Harvey (2001) who assert that employers want graduates who can use their abilities and skills to evolve the organisation, participate in innovative team-work, do critical thinking on issues that will add values to the organisation. Similarly, Malaysian Today (2005) revealed the result of a survey conducted by Malaysian government on university graduates' employability skills and found that about 60,000 Malaysian graduates were unemployed because of lack of experience, poor English communication skills and study of courses that are not relevant to the market needs. In the same vein, Pauw, Ooshuizen and Westhuizen (2008) found that in South Africa, many university graduates were not employed because they lack soft skills and work place readiness. So also in Ghana, Boateng and Ofori-Sarpong (2002) found that employers often reject university graduates who lack the basic skills to complete simple routine assignments.

On employers perceived ratings of skills possessed by university graduates, Table 2 showed that they only possessed skills in English proficiency and literacy and ICT skills even though at an average level. Responsible for these skills may be medium of instruction in the university and current trends in the use ICT gadgets ranging from cell phones, ipads to computer. It was however found that an average university graduate lacks decision-making skills, team-work skills, leadership skill and analytical and problem solving skills which ordinarily should aid their existence and survival within and outside work environments. Moreover, if employers from the four sectors sampled in this study could rate graduates' possessed skill so low, it could be due to some deficiencies in the university curriculum, content and mode of instruction and level of students' exposure to realities of life. However, these deficiencies may be attributed to some major challenges facing Nigarian universities. These among others include underfunding, poor research grants, poor infrastructure and importantly, poor town-gown relationship. This argument confirms Pitan and Adedeji (2012) position that there was a disparity between the skills acquired by university graduates and the ones needed by employers of labour. Similarly, Nurita, Shharudin and Ainon (2004) in their study observe that the general consensus among employers indicate that graduates lack employability skills. This is because employers expectations are more than being proficient in English language but the ability to present ideas, explain issues and 
challenges, speak up in a constructive manner, resolve issues, understand challenges faced by organisations and come up with workable solutions.

Interestingly, the results obtained in Table 3 showed that no significant difference existed between public and private university graduates on their skills as perceived by the employers. This may explain the reasons why De la Harpe et. al. (2000), Oni (2001) Adams (2006), Pitan and Adedeji (2012) and Adebakin (2014) observed that graduates turned out from Nigerian private and public universities are not found employable due to the compromised standards, infrastructural decay and inadequate employability skills. Based on this, it becomes worrisome to discover that both public and private organisations are discouraged from employing them. This is because the employers have to incur additional cost to train and retain them to fit into the organisational operations. Moreover, the huge resources used in the training programmes have serious impact on their profit margin. This may explain why most banks, schools, telecommunications and manufacturing industries would prefer to employ Diploma or Certificate holders who will be trained and remunerated low in order to maximize profit.

\section{Conclusion}

In today's complex work environment, it becomes a challenge for Nigerian universities to equip and internalize in the young people critical thinking skills, creativity, information processing, decision-making, conflict management and resolution skills, team-work and leadership competences. Teaching such life skills can be added into every aspect of the university curricular with appropriate teaching skills that encourage interactive learning, knowledge application to real life problems, peer tutoring and the likes.

\section{Recommendations}

Findings from this study have shown that skill constraints are the major issues Nigeria University graduates faced. The study therefore suggests that town-gown relationship should be re-invigorated by inviting the industries to interact with students while in the university in order to prepare their minds for what they might likely face and employers' expectations of them after graduation. Nigeria as a country with 128 universities should have ordinarily enjoyed a legacy of high skill endowments. However, measures should be taken to ensure redefinition of university curricular, mode of instruction and development of more of the affective and psychomotor skills than the cognitive aspect of learners. Employers required skills should be introduced as a practical course with relevant field trips attached. This should be made compulsory in all Nigerian universities and serve as criterion for employability in the Nigerian labour market as it will improve the employment prospects of Nigerian university graduates.

\section{References}

Adams, A. V. (2006). The role of skills development in the transition to work: A global review. Background Paper for the World Development Report 2007.

Adebakin, A. B. (2014). Assessment of University Graduates' Employability and Productivity in Public and Private Organisations in Lagos State. Unpublished M.A (Ed) thesis, Department of Educational Management, Obafemi Awolowo University, Ile-Ife.

Adepoju, T. L., \& Fadokun, J. B. (2009). Higher education and youth preparation for labour market: Implication for economic growth in Nigeria. Journal of Education Review, 2(2), 185-193.

Boateng, K., \& Ofori-Sarpong, E. (2002). An analytical study of the labor market for tertiary graduates in Ghana (p. 88). World Bank/National Council for Tertiary Education and the National Accreditation Board Project.

Chang, M. (2004). Why some graduates are more marketable than others: Employers' perspective. Paper presented at the workshop on enhancing graduate employability in a globalised economy, Economic Planning Unit, Malaysia.

De la Harpe, B., Radloff, A., \& Wyber, J. (2000). Quality and generic skills. Quality in Higher Education, 6(3), 231-243. http://dx.doi.org/10.1080/13538320020005972

Dearing, R. (1997). Higher education in the learning society. Report of the national committee of inquiry into higher education. Norwich: HMSO.

Dunne, E., Bennet, N., \& Carré, C. (2000). Skill development in higher education and employment. In F. Coffield (Ed.), Differing visions of a learning society. Research findings, Vol.1. UK: The Policy Press \& ESRC. 
Federal Government of Nigeria (2004). National policy on Education. Lagos: NERDC.

Harvey, L. (2001). Defining and measuring employability. Quality in Higher Education, 7(2), 97-109. http://dx.doi.org/10.1080/13538320120059990

Harvey, L., \& Bowes, L. (1998). The impact of work experience on the employability of graduates. Birmingham: University of Central England.

Harvey, L., Locke, W., \& Morey, A. (2002). Enhancing employability, recognising diversity: Making links between higher education and the world of work. London: University Press.

Hillage, J., \& Pollard, E. (1998). Employability: Developing a framework for policy analysis. Research brief 85, Department for Education and Employment.

Holmes, L. (2001). Reconsidering graduate employability: The 'graduate identity' approach. Quality in Higher Education, 7(2), 111-119. http://dx.doi.org/10.1080/13538320120060006

Kamal, K. (2006). Training employable graduates: Innovation in training methodology. Paper presented at National Conference on Continuing Technical Education \& Training, the Katerina Hotel, Batu Pahat Johor.

Knight, P., \& Yorke, M. (2001). Employability through the curriculum. Skills Plus Project.

Lawrence, T. (2002). Teaching and assessing employability skills through skills in USA. Annual Quality Congress Proceedings, ABI/INFORM Global, 56, 285-294.

Little, B. (2001). Reading between the lines of graduate employment. Quality in Higher Education, 7(2), 121-129. http://dx.doi.org/10.1080/13538320120060015

Malaysia Today (2005, June 5). Malaysia has 60,000 graduates unemployed. Retrieved from http://www.malaysia-today.net/Blog-e/2005/11/malaysia-has-60000-undergraduates.htm

Nurita, D. Shaharudin, D., \& Ainon, N. (2004). Perceived employability skills of graduating students: Implications for SMEs. Journal of Entrepreneurship, 8(2), 45-55.

Oni, B. (2001). Labour market prospects of university graduates in Nigeria. Paper Presented at the Stakeholders Conference on Curriculum Review for University Education in Nigeria, NUC, Abuja.

Pauw, K. M., Oosthuizen, J., \& Westhuizen, C. V. (2008). Graduate unemployment in the face of skills shortages: A labour market paradox. South African Journal of Economics, 76(1), 45-57. http://dx.doi.org/10.1111/j.1813-6982.2008.00152.x

Pierce, D. (2002). Employability: Higher education and careers services. In Yorke, M. (Ed.), Learning \& Employability. New York: ESECT.

Pitan, O. S., \& Adedeji, S. O. (2012). Skills Mismatch among University Graduates in the Nigeria Labor Market. US-China Education Review, A(1), 90-98.

Raybould, J., \& Sheard, V. (2005). Are graduates equipped with the right skills in the employability stakes? Industrial \& Commercial Training, 5, 259-263. http://dx.doi.org/10.1108/00197850510609694

Smith, J., McKnight A., \& Naylor, R. (2002). Graduate employability: Policy and performance in higher education in the UK. The Economic Journal, 110, 382-411. http://dx.doi.org/10.1111/1468-0297.00546

Stewart, J., \& Knowles, V. (2000). Graduate recruitment and selection: Implications for HE, graduates and small business recruiters. Washington DC: Lahmp.

Suresh, R. (2006). $70 \%$ of grads from public institutions jobless. Retrieved from http://www.sun2surf.com/article.cfm?id=1466

Yorke, M. (2001). Employability in the first cycle higher education. A working paper for the 'Skills Plus' Project. Liverpool: John Moores University. 